\title{
Heavy metal concentrations in Cipangopaludina chinensis (Reeve, 1863) and relationships with sediments in Saint-Augustin Lake, Québec City (Qc, Canada)
}

\author{
Ombretta Tornimbeni ${ }^{1 *}$, Rosa Galvez ${ }^{2}$, Gaëlle Triffault-Bouchet ${ }^{3}$, Nathalie Dassylva ${ }^{4}$ \\ and Steeve Roberge ${ }^{4}$ \\ ${ }^{1}$ CNR Institute of Ecosystem Study, Largo Tonolli 50, 28922 Verbania Pallanza, Italy \\ 2 Civil Engineering Departement, Laval University, Pavillon Adrien Pouliot Building, Avenue de la Médecine, Québec, Canada \\ ${ }^{3}$ Division Écotoxicologie et Évaluation du Risque, Centre d'Expertise en analyse environnementale du Québec, Ministère du \\ Développement Durable, de l'Environnement et des Parcs, Complexe Scientifique, 2700 rue Einstein, Bureau E-2-220, Ste-Foy \\ (Québec), G1P 3W8 Canada \\ ${ }^{4}$ Centre d'Expertise en analyse environnementale du Québec, Direction de l'analyse et de l'étude de la qualité du milieu, 2700 rue \\ Einstein, Ste-Foy (Québec), G1P-3W8 Canada
}

\section{Received 3 August 2012; Accepted 20 December 2012}

\begin{abstract}
Saint-Augustin Lake is an urban lake in Québec, Canada that has been subjected to long periods of direct human impact, mainly due to agricultural and urban activities, with great changes in trophic status and chemistry occurring within the last few decades. In 2009, during an examination of the lake bottom substrate, the presence of the invasive species Cipangopaludina chinensis (Reeve, 1863) was found on floor bottom sediments. The gastropods soft tissues were mineralized and analyzed by ICP-OES. The purpose of this study was to estimate concentrations of heavy metals in $C$. chinensis, describing the relations of these values with the sediment metal. In gastropod soft tissues the overall common trend in the heavy metal concentrations was revealed in the following order: $\mathrm{Fe}>\mathrm{Mn}>\mathrm{Zn}>\mathrm{Cu}>\mathrm{As}>\mathrm{Ni}>\mathrm{Pb}>\mathrm{Cd}>\mathrm{Cr}$. Biota-sediment accumulation factors (BSAFs) have shown that $C$. chinensis cannot be used as a bioindicator of heavy metal pollution and exposure in the Canadian lakes where it is present. In fact, while the sediments of Saint-Augustin Lake are characterized by high metal concentrations, $C$. chinensis does not have high bioaccumulation factors (BSAFs $<1.0$ ). By literature comparison with other aquatic organisms in polluted ecosystems at different latitudes it was possible to affirm that the concentrations of $\mathrm{Fe}, \mathrm{Mn}$ and $\mathrm{Zn}$ in C. chinensis tissues are considerable if compared with these sites.
\end{abstract}

Key words: Alloctone species / invasion / bioaccumulation / heavy metals / freshwater / gastropods

\section{Introduction}

Freshwater ecosystems are being extremely altered by human activities, resulting in a decline of the native species and subsequent replacement and spread of new invasive species (Holeck et al., 2004; Kim and Kim, 2006). Gastropods are among those species that can cause extensive changes to the native aquatic communities and the habitats when introduced in new ecosystems. Moreover, many studies have revealed that gastropods could accumulate heavy metals in their soft tissues, metal concentration varying according to the species and their inhabitation environment (Lau et al., 1998; Fang, 2006).

\footnotetext{
*Corresponding author. o.tornimbeni@ise.cnr.it
}

The heavy metals accumulated in the tissues have a potential to be transferred to organisms at higher trophic levels because gastropods are frequently consumed by other animals including humans and birds as a protein source (Saha et al., 2006).

Cipangopaludina chinensis (Reeve, 1863) or Chinese mystery snail is a freshwater gastropod native to South East Asia, Japan, China, Korea and e Eastern Russia. It was originally introduced into North America probably via the aquarium trade, water gardening industry or for culinary purposes through the Chinese market. The first well-established population was reported in 1911 by Hannibal on the corridor between San Francisco Bay and San Jose (http://www.issg.org/database). This imported species has invaded freshwater bodies across 
Table 1. Main morphometric and hydrological characteristics of Saint-Augustin Lake.

\begin{tabular}{llc}
\hline Characteristic & Units & Value \\
\hline Lake level & $\mathrm{m}$ a.s.l. & 41 \\
Watershed area (Wa) & $\mathrm{km}^{2}$ & 7.46 \\
Lake area (La) & $\mathrm{km}^{2}$ & 0.6 \\
Wa/La ratio & & 12.4 \\
Lake perimeter & $\mathrm{km}$ & 4.5 \\
Maximum depth & $\mathrm{m}$ & 6.1 \\
Mean depth & $\mathrm{m}$ & 3.5 \\
Volume & $10^{6} \mathrm{~m}^{3}$ & 2.31 \\
Water renewal time & $\mathrm{Y}$ & 0.5 \\
\hline
\end{tabular}

North America, forming isolated but dense populations in about 27 states of the Unites States and in Canada, originally in Ontario (Rixon et al., 2005) but also recently reported in Québec (http://www.invasivestrac kingsystem.ca).

This snail prefers lentic water bodies with silt, sand, and mud substrates (Distler, 2003) with maximum depth of about $0.2-3 \mathrm{~m}$, although it can tolerate conditions in stagnant waters near septic tanks (Perron and Probert, 1973). C. chinensis is a filter feeder, detritivore and necrophore that feed non-selectively on organic and inorganic matter on lake bottom substrate as well as benthic and epiphytic algae and bacteria (Dillon, 2000). $C$. chinensis bioturbation activities can re-suspend sediments that become a source for phosphorus in the water column (Orvain et al., 2003) which in turn can lead to algal blooms. Re-suspended sediments and algal blooms result in higher turbidity (Orvain et al., 2003) The bioturbation activity can further impact mineralization of organic matter and accelerate nutrient cycling in eutrophic systems (Risgaard-Petersen, 2003; Biswasa et al., 2009).

Finally, C. chinensis can partially bury itself in the mud where the water is still. For all these reasons their relations with sediments are very close.

Since lake sediment plays an important role in freshwater ecosystems as it is both an important source of various dissolved substances and a storage for particulate materials (Boyd, 1995; Gardner et al., 2001) and because of the closed relations of $C$. chinensis with sediment and, probably its contaminants, it is of great interest to study the potential for accumulation of metals in tissues of C. chinensis. Specifically, the aim and objectives of this study were to estimate concentrations of heavy metals in C. chinensis, describing the possible relations of these values with the sediment metal and to evaluate the possibility to use gastropods as a bio-indicator of heavy metal exposure reflecting the level of heavy metals in the sediments.

\section{Methodology}

\section{Study area}

Table 1 and Figure 1 show the location and morphometric characteristics of Saint-Augustin Lake (N 46 $\left.45^{\prime} 05^{\prime \prime}, \mathrm{W} 71^{\circ} 23^{\prime} 39^{\prime \prime}\right)$, respectively. The lake is located near Québec City (Québec, Canada) and was subjected for years to high anthropic pressures due to agricultural and urban activities (Galvez-Cloutier et al., 2003), with a documented sediment contamination in heavy metals (Brin, 2007). The Lake Saint-Augustin is characterized by muddy-sand sediments with an important content of organic matter. About $40.6 \%$ of sediments are composed of silt and $44.7 \%$ of fine sand, while the organic matter content represents about $11.2 \%$. This is representative for the whole basin lake (Brin, 2007). They can be regarded as a specific potential source of pollutants being able to migrate toward the water column. High concentrations of heavy metals contained in the sediments mainly from industrial and urban inputs (Blais and Kalff, 1993; Boyle, 2001) were found reflecting the growing industrialization of the Québec City region (Pienitz et al., 2006). Previous studies on heavy metals speciation have shown that their overall availability is low. In fact, the presence of organic matter, in aerobic conditions, plays a role of reservoir that accumulates heavy metals in sediments in stable form. However, in an anoxic environment these bonds are weaker. Furthermore, a great impact on the ecosystem is due to the salt contributions $(\mathrm{NaCl})$ from the highway network Félix Leclerc, located at the north of the lake and characterized by high traffic activity (Morteau et al., 2009).

During 2009, a preliminary examination of the lake bottom substrate, before the installation of a research platform of Department of Civil Engineering of Laval University of Québec, has revealed the presence of the invasive species $C$. chinensis on Saint-Augustin Lake's floor bottom sediments (Fig. 2). This species is ovoviviparous; females live up to 5 years, while males live up to 3 , occasionally 4 years (Jokinen, 1982, 1992). Fecundity is usually more than 169 young in a lifetime, and may reach up to 102 for any given brood (Jokinen, 1982). All females generally contain embryos from May to August and young are born from June to October in eastern North America in shallow water, then, in the fall, females begin migrating to deeper water for the winter (Stanczykowska et al., 1971; Jokinen, 1982, 1992).

Snail samples were collected in clean plastic bags from three points along the lake during the summer of 2011 (Fig. 3). In sampling site 1 (SS1), in the north-west, the samples collected were all dead. In this area, the sediments were very rich in mud; in sampling site 2 (SS2), in the mid-west, corresponding to harder sediments, $95 \%$ of snails were alive, and at the last sampling site 3 (SS3) in the south, the percentage of living vs. dead snails was about $50 \%$.

\section{Chemical analysis}

Water samples were analyzed for the main chemical variables in the chemical laboratory at the CNR Institute of Ecosystem Study (Italy); pH, conductivity, alkalinity by acidimetric titration (Gran's method), main anions (sulfate, nitrate and chloride), and cations (calcium, 


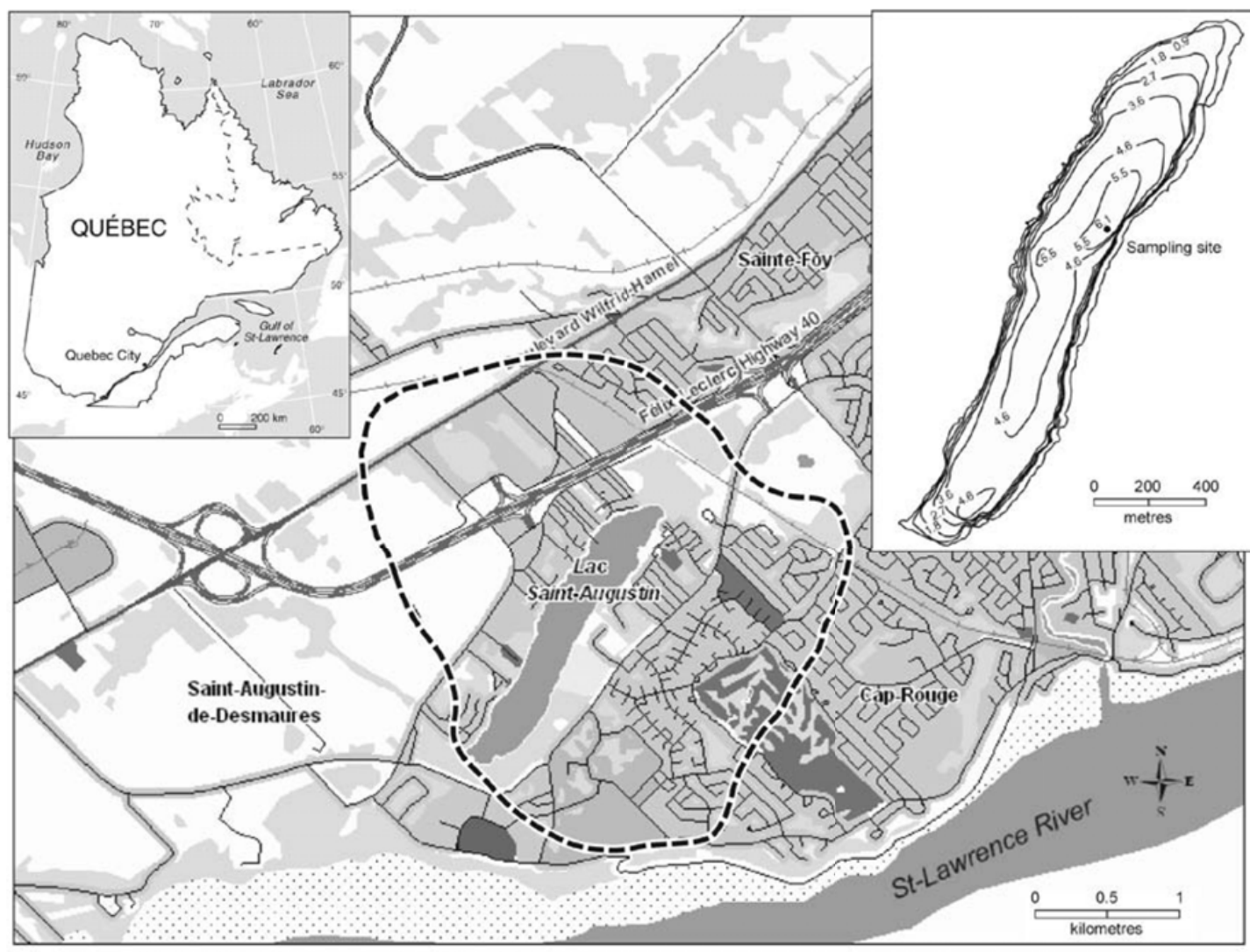

Extent of drainage basin (catchment)

Fig. 1. Map showing the location of Saint-Augustin Lake within western suburban Québec City.

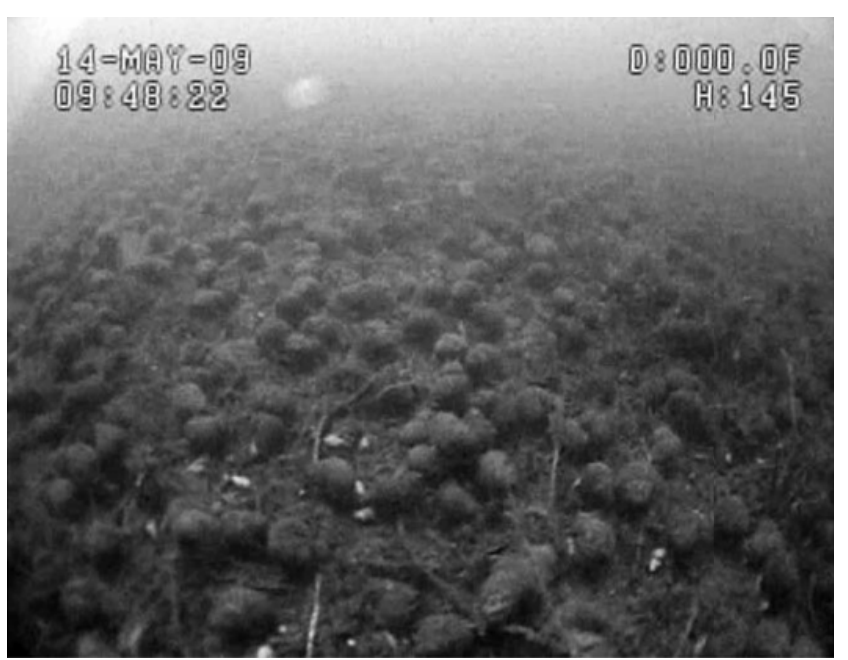

Fig. 2. Underwater photo of the lakebed in the Saint-Augustin Lake that revealed massive invasion by C. chinensis.

magnesium, sodium, and potassium) by ion chromatography; ammonium, reactive silica, and reactive and total phosphorus by spectrophotometry (indophenol-blue and ammonium molybdate with ascorbic acid, respectively). Details on the analytical methods used can be found in Tartari and Mosello (1997).
Significantly there was sodium chloride contamination in water $\left(\mathrm{Na}^{+}, 2913 \mu \mathrm{eq} \mathrm{L}^{-1}\right.$ and $\mathrm{Cl}^{-}, 2981 \mu$ eq $\left.\mathrm{L}^{-1}\right)$.

Trace metals in water and in mineralized tissues of snails were measured by ICP-OES (inductively coupled plasma-optical emission spectrometer). The concentration of dissolved trace metals in freshwater was usually low. The solubility of metals in surface water is predominately controlled by water pH (8.26 in Saint-Augustin Lake), the type and concentration of ligands on which the metal could adsorb, and the oxidation state of the mineral components and the redox environment of the system (Connell and Miller, 1984). Arsenic, cadmium, platinum, and thallium were below the detection limits of the method used. A group of metals that includes: aluminum, cobalt, chromium, copper, manganese, nickel, lead, and zinc too, presented very low concentrations (between 0.3 and $7.2 \mu \mathrm{g} \mathrm{L}^{-1}$ ). In contrast, values of boron, iron, lithium, and vanadium (between 10.8 and $33.7 \mu \mathrm{g} \mathrm{L}^{-1}$ ) and especially barium and strontium, mainly in relation to the lithological characteristics of the catchment area were higher (105 and $599 \mu \mathrm{g} \mathrm{L}^{-1}$, respectively).

\section{Digestion sample processing and dosage of heavy metals}

Sample tissues for analysis were prepared at the CEAEQ laboratory following the MA 207- Mét 2.0 


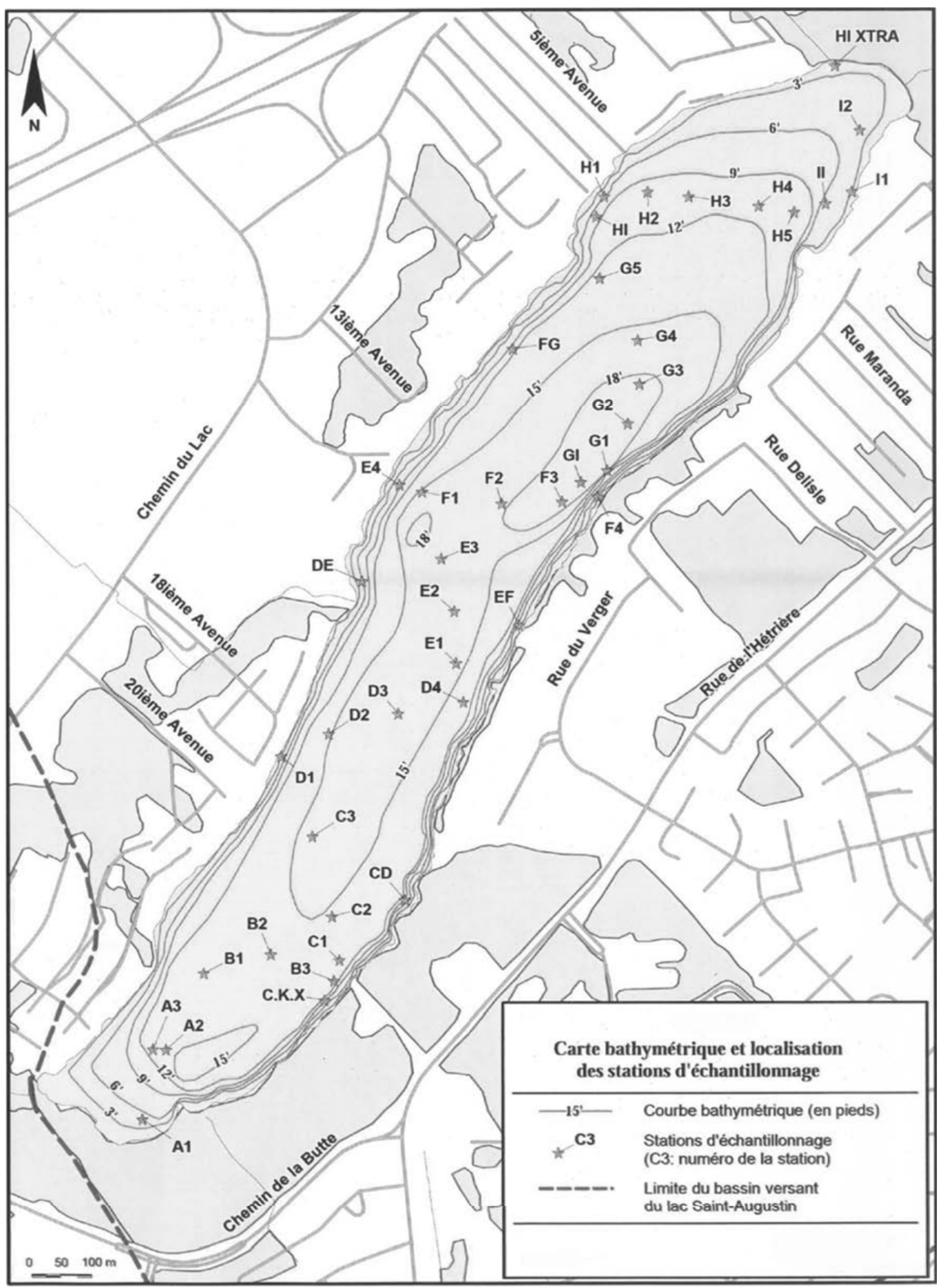

Fig. 3. Location of the sampling sites for snails in Saint-Augustin Lake (SS1, SS2, and SS3). In the figure are also shown the sampling sites for sediments (Brin, 2007).

method developed by CEAEQ (Dassylva et al., 2009; Roberge, 2011). Wet snail tissues were dehydrated before digestion, using a lyophilizer (Freezone 4.5; Labconco, Kansas City, Missouri, USA); $0.5 \mathrm{~g}$ of tissue samples were placed into $20 \mathrm{~mL}$ glass vials and the sample vials were placed together into lyophilization vessels. The samples were dried for a night at the minimum temperature of $-50{ }^{\circ} \mathrm{C}$. After lyophilization the weight loss was $\sim 36 \%$ of total mass.

Dry samples were digested using a MarsXpress microwave digester (CEM, Mattews, USA). A $25 \mathrm{~mL}$ PFA Teflon close vessel (CEM) was used and $0.1 \mathrm{~g}$ of the sample 
Table 2. Microwave parameters for snail tissues digestion.

\begin{tabular}{lllll}
\hline Max power & \% Power used & Ramp temperature time & Temperature & Holding time \\
\hline $1600 \mathrm{~W}$ & 85 & $15: 00 \mathrm{~min}$ & $195^{\circ} \mathrm{C}$ & $15: 00 \mathrm{~min}$ \\
\hline
\end{tabular}

Table 3. Trace metal mass fractions $\left(\mathrm{mg} \mathrm{kg}^{-1}\right)$ and measured values in fish protein certified reference materials for trace metals (DORM-3, NCR-CNRC). $R(\%)$ : degree of recovery.

\begin{tabular}{lccr}
\hline Element & $\begin{array}{c}\text { Certified values } \\
\left(\mathrm{mg} \mathrm{kg}^{-1}\right)\end{array}$ & $\begin{array}{c}\text { Measured values } \\
\left(\mathrm{mg} \mathrm{kg}^{-1}\right)\end{array}$ & $R(\%)$ \\
\hline $\mathrm{As}$ & $6.88 \pm 0.30$ & $5.43 \pm 0.74$ & 82 \\
$\mathrm{Cr}$ & $1.89 \pm 0.17$ & $1.90 \pm 0.11$ & 100 \\
$\mathrm{Cu}$ & $15.5 \pm 0.63$ & $19.4 \pm 2.82$ & 120 \\
$\mathrm{Fe}$ & $347 \pm 20$ & $360 \pm 26$ & 100 \\
$\mathrm{Ni}$ & $1.28 \pm 0.24$ & $0.90 \pm 6.17$ & 88 \\
$\mathrm{Zn}$ & $51.3 \pm 3.10$ & $55.8 \pm 4.21$ & 103 \\
\hline
\end{tabular}

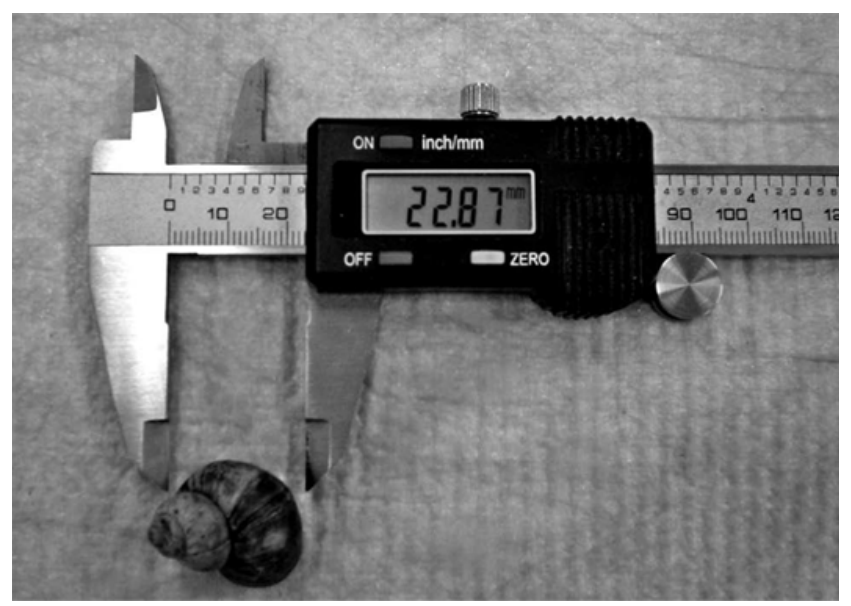

Fig. 4. Measurements made on shells with an electronic digital caliper.

was transferred into the vessel. $1 \mathrm{~mL}$ of concentrated $\mathrm{HCl}$ and $3 \mathrm{~mL}$ of concentrated $\mathrm{HNO}_{3}$ were added to the sample. Then, the samples were placed in the microwave digester. Table 2 shows the microwave parameters.

After the digestion, the samples were transferred and filled to $50 \mathrm{~mL}$ with deionized water (18 $\mathrm{M} \Omega$; Millipore, USA) into a $50 \mathrm{~mL}$ polypropylene decontaminated tube (Digitubes, SCP Sciences, Baie D'Urfé, QC, Canada) mass fractions (ada).

Trace metals in mineralized tissues of snails were measured by ICP-OES according to US EPA Method 3020A (1992). Tables 3 and 4 show those elements for which certified values have been established for DORM-3 (Fish protein) and TORT-2 (Lobster hepatopancreas) standard biological reference materials. Certified values and their uncertainties are reported as mass fractions (based on dry mass). These reference materials, result from data generated at the National Research Council of Canada, and they are primarily intended for use in the calibration of procedures and the development of methods, as well as for determination of trace metals in biological materials.
Table 4. Trace metal mass fractions $\left(\mathrm{mg} \mathrm{kg}^{-1}\right)$ and measured values in lobster hepatopancreas reference material for trace metals (TORT-2, NCR-CNRC). $R(\%)$ : degree of recovery.

\begin{tabular}{lccr}
\hline Element & $\begin{array}{c}\text { Certified values } \\
\left(\mathrm{mg} \mathrm{kg}^{-1}\right)\end{array}$ & $\begin{array}{c}\text { Measured values } \\
\left(\mathrm{mg} \mathrm{kg}^{-1}\right)\end{array}$ & $R(\%)$ \\
\hline $\mathrm{As}$ & $21.6 \pm 1.8$ & $23.2 \pm 1.1$ & 99 \\
$\mathrm{Cd}$ & $26.7 \pm 0.6$ & $29.5 \pm 1.5$ & 108 \\
$\mathrm{Cr}$ & $0.77 \pm 0.15$ & $0.90 \pm 0.12$ & 98 \\
$\mathrm{Cu}$ & $106 \pm 10$ & $116 \pm 2.69$ & 100 \\
$\mathrm{Fe}$ & $105 \pm 13$ & $108 \pm 39$ & 103 \\
$\mathrm{Mn}$ & $13.6 \pm 1.2$ & $15.1 \pm 0.2$ & 102 \\
$\mathrm{Ni}$ & $2.50 \pm 0.19$ & $2.10 \pm 4.89$ & 100 \\
$\mathrm{~Pb}$ & $0.35 \pm 0.13$ & $0.62 \pm 0.08$ & 130 \\
$\mathrm{Zn}$ & $180 \pm 6$ & $198 \pm 16$ & 106 \\
\hline
\end{tabular}

Table 5. Significant levels of morphometric parameters and grain size composition of the bottom of the Saint-Augustin Lake: $*<5 \%$; $* *<1 \%$; n.s. non significant.

\begin{tabular}{llll}
\hline Sampling sites & Width & Height & $\begin{array}{c}\text { Sediment } \\
\text { granulometry }\end{array}$ \\
\hline SS1 vs. SS2 & $* *$ & $* *$ & $* *$ \\
SS1 vs. SS3 & $*$ & $*$ & $* *$ \\
SS2 vs. SS3 & n.s. & n.s. & $*$ \\
\hline
\end{tabular}

SS1: $100 \%$ of snails died; SS2: $95 \%$ of snails alive; $\mathrm{SS} 3: 50 \%$ of snails alive.

\section{Results and discussion}

\section{Morphometry, abundance/biomass and distribution}

C. chinensis is a large globose freshwater snail that may reach a shell length of up to $70 \mathrm{~mm}$ (Solomon et al., 2010). In the Saint-Augustin Lake, it exhibits a robust morphology with a width to height ratio of 0.85:0.90, a mean shell length of $23.5 \mathrm{~mm}$ (measured from the apex to the basal inflection of the aperture with an electronic digital caliper as shown in Figure 4) and a mean weight of $2.5 \mathrm{~g}$. Fresh tissue was about $46 \%$ of total weight of snail. Total C. chinensis biomass (shell and soft tissue) was expressed in milligrams of fresh weight per square meter $\left(\mathrm{mg} \mathrm{m}^{-2}\right)$, while the abundance as the number of individuals per square meter. In the Saint-Augustin Lake, the presence of snails on the bottom is uniform and it is possible to affirm that the abundance values were about 650-700 individuals per square meter, while the biomass values, except for SS1, where all individuals found were dead, were between 1625 and $1750 \mathrm{mg} \mathrm{m}^{-2}$.

The $t$-test (Table 5) performed on the morphometric parameters measured (width and height) and sediment granulometry (Brin, 2007) at the three sampling sites showed significantly high values for SS1 that is 
Table 6. Mean heavy metals concentrations $\left(\mathrm{mg} \mathrm{kg}^{-1}\right)$ and standard deviation in the sample sediments $(n=42)$ in Saint-Augustin Lake for arsenic, cadmium, chrome, copper, nickel, lead and zinc (Brin, 2007). Mean heavy metals concentrations (mg $\mathrm{kg}^{-1}$ ) in surficial sediments in Saint-Augustin Lake for iron and manganese (Pienitz et al., 2006). Mean heavy metals concentrations $\left(\mathrm{mg} \mathrm{kg}^{-1}\right)$ in the sample snails (C. chinensis) into two sampling sites in Saint-Augustin Lake. SS2: sampling site 2; SS3: sampling site 3.

\begin{tabular}{lccc}
\hline & & Sampling site & \multicolumn{1}{c}{ SS3 $\left(\mathrm{mg} \mathrm{kg}^{-1}\right)$} \\
\cline { 2 - 4 } & Sediments $\left(\mathrm{mg} \mathrm{kg}^{-1}\right)$ & $\mathrm{SS} 2\left(\mathrm{mg} \mathrm{kg}^{-1}\right)$ & $47 \pm 5.5$ \\
$\mathrm{Al}$ & & $97 \pm 9.2$ & $2.4 \pm 0.7$ \\
$\mathrm{As}$ & $6.9 \pm 1.1$ & $1.9 \pm 0.8$ & $24 \pm 18.6$ \\
$\mathrm{~B}$ & & $25 \pm 17.8$ & $40 \pm 4.8$ \\
$\mathrm{Ba}$ & $2.3 \pm 0.7$ & $58 \pm 4.1$ & $0.70 \pm 0.6$ \\
$\mathrm{Cd}$ & & $0.41 \pm 1.5$ & $3.91 \pm 12.3$ \\
$\mathrm{Co}$ & $25 \pm 7.9$ & $4.72 \pm 10.0$ & $0.20 \pm 0.2$ \\
$\mathrm{Cr}$ & $39 \pm 11.4$ & $0.40 \pm 0.1$ & $9.7 \pm 3.0$ \\
$\mathrm{Cu}$ & 32000 & $12.0 \pm 2.7$ & $112 \pm 37.2$ \\
$\mathrm{Fe}$ & 967 & $337 \pm 25.3$ & $36 \pm 0.7$ \\
$\mathrm{Mn}$ & $39 \pm 11.7$ & $102 \pm 1.1$ & $0.8 \pm 5.3$ \\
$\mathrm{Ni}$ & $75 \pm 29.5$ & $1.3 \pm 5.7$ & $0.8 \pm 0.1$ \\
$\mathrm{~Pb}$ & & $1.2 \pm 0.1$ & $1.5 \pm 25.2$ \\
$\mathrm{Se}$ & $272 \pm 85.3$ & $3.5 \pm 15.2$ & $60 \pm 11$ \\
$\mathrm{Zn}$ & & $54 \pm 16.3$ & \\
\hline
\end{tabular}

characterized by the presence of mud and clay (grain size $0.05 \mu \mathrm{m}$, in accordance with the USDA - United States Department of Agriculture and confirmed also by ISSS The International Society for the Systems Sciences) where the snails sampled died. SS2 and SS3, characterized by ground composed mostly of medium sand (about $83 \%$ with grain size about $556 \mu \mathrm{m})$ and coarse sand $(17 \%$ with grain size $>600 \mu \mathrm{m}$ ) in which live snails were sampled, showed non-significant results. This could be due to the lower affinity of $C$. chinensis in this type of ecosystem with soft clayey ground.

\section{Evaluation of heavy metal bioaccumulation in C. chinensis}

All aquatic organisms can concentrate heavy metals from their surrounding water, sediments or food and they are able to regulate the concentrations of metals in their tissues, to be stored in non-available forms and hence regulate toxic effects by controlling absorption, excretion, and depuration rates or by detoxification either by changing the metal to a less toxic form or by storage at sites in the body where the metal does not have an adverse effect (Hugget et al., 1973). The mean heavy metals concentration for sediments in the lake and mean heavy metals concentration for snails into two different sampling sites are shown in Table 6.

Metals are present in the lake sediment at concentrations at which the probability to detect adverse biological effects is relatively high. Indeed, concentrations are between the occasional effect level (OEL) and the frequent effect level (FEL) determined by Environment Canada and the Environmental Ministry of Quebec (Environment Canada and MDDEP, 2007) for the management of sediments that have to be dredged: $\mathrm{Cd}\left(\mathrm{OEL}=1.7 \mathrm{mg} \mathrm{kg}^{-1}\right.$ and $\left.\mathrm{FEL}=12 \mathrm{mg} \mathrm{kg}^{-1}\right), \mathrm{Pb}$ $\left(\mathrm{OEL}=52 \mathrm{mg} \mathrm{kg}^{-1}\right.$ and $\left.\mathrm{FEL}=150 \mathrm{mg} \mathrm{kg}^{-1}\right)$, and $\mathrm{Zn}$ $\left(\mathrm{OEL}=170 \mathrm{mg} \mathrm{kg}^{-1}\right.$ and $\left.\mathrm{FEL}=770 \mathrm{mg} \mathrm{kg}^{-1}\right)$.

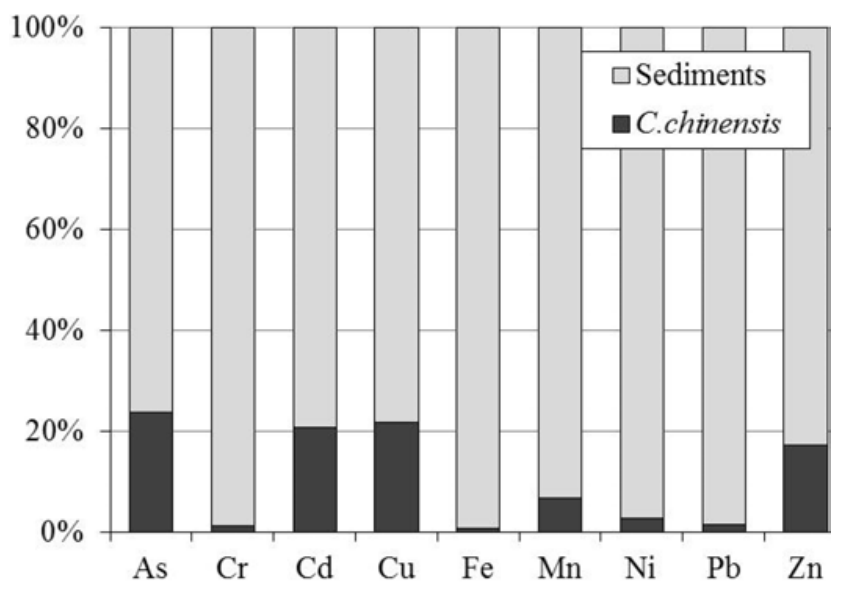

Fig. 5. Comparison (\%) between the mean concentrations of selected heavy metals in snails collected in Saint-Augustin Lake and sediments.

The level of some metals found in snails seems to vary depending on the sampling sites. Snails collected in SS2 have significantly higher amount of aluminum (96.9 vs. $46.5 \mathrm{mg} \mathrm{kg}^{-1}$ ), iron (336.9 vs. $111.6 \mathrm{mg} \mathrm{kg}^{-1}$ ), and manganese (101.9 vs. $35.7 \mathrm{mg} \mathrm{kg}^{-1}$ ) when compared with those obtained from SS3 (Table 5). This demonstrates that there is influence of habitat on the level of some metals in the organisms.

Biota-sediment accumulation factors (BSAFs) are appropriate for describing bioaccumulation of sediment contaminants in aquatic food webs with non-equilibrium conditions, between the sediment and organism, and sediment and its overlying water (Thomann et al., 1992; Burkhard, 2009). Equilibrium is regarded as a reference condition for describing degrees of disequilibrium, and thus, is not a requirement for measurement, prediction, or application of BSAFs. 
Table 7. BSAFs: biota-sediment accumulation factors (C. chinensis) into two sampling sites in Saint-Augustin Lake. SS2: sampling site 2; SS3: sampling site 3 .

\begin{tabular}{|c|c|c|c|c|c|c|c|c|c|}
\hline Sampling site & As & $\mathrm{Cd}$ & $\mathrm{Cr}$ & $\mathrm{Cu}$ & $\mathrm{Fe}$ & $\mathrm{Mn}$ & $\mathrm{Ni}$ & $\mathrm{Pb}$ & $\mathrm{Zn}$ \\
\hline$\overline{\mathrm{SS} 2}$ & 0.28 & 0.17 & 0.02 & 0.31 & 0.01 & 0.11 & 0.03 & 0.02 & 0.20 \\
\hline SS3 & 0.35 & 0.30 & 0.01 & 0.25 & 0.003 & 0.12 & 0.02 & 0.01 & 0.22 \\
\hline
\end{tabular}

Table 8. Mean concentrations of heavy metals in C. chinensis in Saint-Augustin Lake, compared with other filter feeders, in different ecosystems. All values in $\mathrm{mg} \mathrm{kg}^{-1}$ in dry tissue.

\begin{tabular}{|c|c|c|c|c|c|c|c|c|c|}
\hline Area & Species & $\mathrm{Cd}$ & $\mathrm{Cu}$ & $\mathrm{Cr}$ & $\mathrm{Fe}$ & $\mathrm{Mn}$ & $\mathrm{Ni}$ & $\mathrm{Pb}$ & $\mathrm{Zn}$ \\
\hline Canada $^{\mathrm{a}}$ & C. chinensis & 0.6 & 10.8 & 0.3 & 224.3 & 68.8 & 1.05 & 1.0 & 56.9 \\
\hline India $^{b}$ & Angulyagra oxytropis & 1.3 & & 5.8 & 691.7 & 167.9 & 93.6 & 22.9 & 177.9 \\
\hline Nigeria $^{\mathrm{c}}$ & Lanistes lybicus & & & & 160.0 & & & 18.5 & \\
\hline Argentina $^{\mathrm{d}}$ & Corbicula fluminea & 0.5 & 28.0 & 1.3 & 81.0 & & 1.3 & & 118.0 \\
\hline $\mathrm{USA}^{\mathrm{e}}$ & Elliptio hopetonensis & 1.4 & 5.8 & & & 4396 & 2.0 & 0.9 & 175 \\
\hline Italy $^{\mathrm{f}}$ & Unio Pictorum mancus & & 9.0 & & 1750 & 2874 & & & 136 \\
\hline
\end{tabular}

aPresent study.

${ }^{\mathrm{b}}$ Gupta (1998).

${ }^{\mathrm{c} O l u f e m i}$ et al. (2008).

${ }^{\mathrm{d} B i l o s}$ et al. (1998).

'Shoultz-Wilson et al. (2010).

${ }^{\mathrm{f}}$ Ravera et al. (2003).

The comparison between metal content in sediments and in snails, expressed as percentage, shows great differences for all metals as presented in Figure 5. Results indicate that metals are weakly accumulated in soft tissues of C. chinensis. BSAFs (Table 7) are all less than 1.0 and for several metals well below $1.0(\mathrm{Cr}, \mathrm{Fe}, \mathrm{Ni}$, and $\mathrm{Pb}$ ). The processes of excretion and detoxification seem to be effective in these organisms. However, hazard and potential for chronic effects cannot be evaluated by magnitude of BSAFs (DeForest et al., 2007), even if the factors are $<1.0$, which indicates that bioaccumulation is not the typical case (Adams, 2011).

$$
\mathrm{BSAF}=C_{\mathrm{org}} / C_{\mathrm{sed}},
$$

where $C_{\text {org }}$ is the heavy metal concentration in organic tissues and $C_{\text {sed }}$ is the heavy metal concentration in sediment.

\section{Comparison of heavy metal concentrations in different organisms}

Median values of the main metals in $C$. chinensis are shown in Table 8, compared with other aquatic organism surveys performed in other countries (by literature). All organisms considered for the comparison are filter feeders, but while Angulyagra oxytropis (Benson, 1836) and Lanistes lybicus (Morelet, 1848) are gastropods, as C. chinensis; Corbicula fluminea (O. F. Müller, 1774), Elliptio hopetonensis (I. Lea, 1838), and Unio pictorum mancus (Lamarck, 1819) are bivalves. The ecosystems selected for this comparison with the Saint-Augustin Lake are under high to moderate anthropic pressure (extensive agriculture, industry or urbanized areas), with a significantly higher contamination of heavy metals in sediment samples.
All organisms revealed significantly greater concentrations of $\mathrm{Fe}, \mathrm{Mn}$, and $\mathrm{Zn}$, (respectively, in a range of 81-1750 mg kg-1 for iron, 69-4396 $\mathrm{mg} \mathrm{kg}^{-1}$ for manganese, and $57-175 \mathrm{mg} \mathrm{kg}^{-1}$ for zinc). The capacity of filter feeders, in particular of mussels to concentrate manganese has been known for about a century (Bradley, 1907a, 1907b). In fact the highest concentrations were measured in E. Hopetonensis (Shoultz-Wilson et al., 2010) and in Unio pictorum mancus (Ravera et al., 2003). Iron is another essential metal, generally abundant in any environment, and has several properties similar to those of manganese.

In any case some heavy metal concentrations found in C. chinensis tissues $(\mathrm{Fe}, \mathrm{Mn}$, and $\mathrm{Zn}$ ) are considerable if compared with other polluted ecosystems at different latitude. These concentrations may cause adverse effects on these organisms. Moreover, the risks for predators of C. chinensis (fish, turtle) should be evaluated.

\section{Conclusions}

The present study has provided evidence that hazard and potential for chronic effects cannot be evaluated by the magnitude of BSAFs. In fact while in the sediments of the Saint-Augustin Lake there are high metal concentrations there is no direct correlation with BSAFs in C. chinensis.

While the sediments of the Saint-Augustin Lake are characterized by high metal concentrations, $C$. chinensis does not have high bioaccumulation factors. Metals were perhaps not bioavailable but above this the results seem to indicate the ability of $C$. chinensis to detoxify or sequester some metals. In this case, $C$. chinensis cannot be used as a bioindicator of heavy metal pollution and exposure in the Canadian lakes where it is present. 
Based on the available information in this screening study on $C$. chinensis in the Saint-Augustin Lake, it is important to emphasize the invasion of the alloctone species C. chinensis in Québec. As regards the impact of snails on human health, it must be considered that eutrophication can increase the growth of snail populations, as in the case of the Saint-Augustin Lake (TP, $18 \mu \mathrm{gL}^{-1}$ during sampling campaign), and can increase also the possibility of transmission of some aquatic parasites that can cause human cercarial dermatitis, also known as "Swimmers itch" (Leighton et al., 2000). Monitoring the trends in the invasive species is an important consideration as they can alter ecosystem structure and function.

Acknowledgements. Special thanks to the staff of the Civil Engineering Department of Laval University, and also to the staff of Centre d'expertise en analyse environnementale du Québec (CEAEQ-MDDEP) for their help in the laboratory.

\section{References}

Adams B., 2011. Bioaccumulation requiring specific attention for metals and inorganics. In: Proceedings of the "OECD meeting, Paris, 7-8 September 2011, Bioaccumulation requiring specific attention for metals and inorganics". [online].

Bilos C., Colombo J.C. and Rodriguez Presa M.J., 1998. Trace metals in suspended particles, sediments and Asiatic clams (Corbicula fluminea) of the Rio de la Plata Estuary, Argentina. Environ. Poll., 99, 1-11.

Biswasa J.K., Ranaa S., Bhaktab J.N. and Jana B.B., 2009. Bioturbation potential of chironomid larvae for the sediment-water phosphorus exchange in simulated pond systems of varied nutrient enrichment. Ecol. Eng., 35, 1444-1453.

Blais J.M. and Kalff J., 1993. Atmospheric loading of $\mathrm{Zn}, \mathrm{Cu}$, $\mathrm{Ni}, \mathrm{Cr}$, and $\mathrm{Pb}$ to lake sediments: The role of catchment, lake morphometry, and physico-chemical properties of the elements. Biogeochemistry, 23, 1-22.

Boyd C.E., 1995. Bottom Soils, Sediment, and Pond Aquaculture, Chapman \& Hall, New York, 340 p.

Boyle J., 2001. Redox remobilization and the heavy metal record in lake sediments: a modelling approach. J. Paleolimnol., 26, 423-431.

Bradley H.C., 1907a. The occurrence of manganese in freshwater clams. Science, 25, 456.

Bradley H.C., 1907b. Manganese. A normal element in the tissues of freshwater clams, Unio and Anodonta. J. Biol. Chem., 3, 151.

Brin M.E., 2007. Étude de la biodisponibilité des contaminants (éléments traces métalliques et phosphore) contenus dans les sédiments du lac Saint-Augustin (Québec), Collection mémoires et thèses de l'Université Laval, Département de Génie Civil, Faculté des Sciences et de Génie, 184 p.

Burkhard L., 2009. Estimation of Biota Sediment Accumulation Factor (BSAF) from Paired Observations of Chemical Concentrations in Biota and Sediment (Final Report). U.S. Environmental Protection Agency, Ecological Risk Assessment Support Center, Cincinnati, OH, EPA/600/ R-06/047, 30 p.
Connell D.W. and Miller G.J., 1984. Chemistry and Ecotoxicology of Pollution, John Wiley \& Sons, New York, $444 \mathrm{p}$.

Dassylva N., Roberge S., Tremblay A. and Ferland H., 2009. Amélioration de la méthode d'analyse des métaux traces dans les tissus animaux par ICP-MS avec l'utilisation du système SC-FAST, (poster presentation), Colloque du Chapitre St-Laurent, 28-29 mai 2009, Montréal, Canada.

DeForest D.K., Brix K.V. and Adams W.J., 2007. Assessing metal bioaccumulation in aquatic environments: the inverse relationship between bioaccumulation factors, trophic transfer factors and exposure concentration. Aquat. Toxicol., 84, 236-246.

Dillon R.T. Jr, 2000. The Ecology of Freshwater Molluscs, Cambridge University Press, Cambridge, 524 p.

Distler D.A., 2003. Occurrence of the mystery snail Cipangopaludina chinensis (Gastropoda: Viviparidae) in the Walnut River basin, Kansas. Trans. Kansas Acad. Sci., 106, 215.

Environment Canada, MDDEP., 2007. Criteria for the assessment of sediment quality in Quebec and application frameworks: prevention, dredging and remediation, Québec, Canada, 39 p.

Fang Z., 2006. Heavy metals in mussels and associated sediments from the coastal sites along the Pearl River Delta, South China. Environ. Toxicol. Chem., 88, 45-55.

Galvez-Cloutier R., Brin M.E., Dominguez G., Leroueil S. and Arsenault S., 2003. Quality evaluation of eutrophic sediments at St-Augustin Lake, Canada. ASTM Special Tech. Publ., 1442, 35-52.

Gardner W.S., Yang L., Cotner J.B., Johengen T.H. and Lavrentyev P.J., 2001. Nitrogen dynamics in sandy freshwater sediments (Saginaw Bay, Lake Huron). J. Great Lakes Res., 27, 84-97.

Gupta A., 1998. Metal accumulation by riverine and lacustrine populations of Angulyagra oxytropis (Benson) (Gasteropoda: viviparidae). Environ. Monit. Assess., 50, 249-254.

Holeck K.T., Mills E.L., MacIsaac H.J., Dochoda M.R., Colautti R.I. and Ricciardi A., 2004. Bridging troubled waters: biological invasions, transoceanic shipping, and the Laurentian Great Lakes. Bioscience, 54, 919-929.

Hugget R.J., Bencher M.E. and Slone H.D., 1973. Utilizing metal concentration relationships in the eastern oyster (Craostrae virginica) to detect heavy metal pollution. Water Res., 7, 151-540.

ISSS - The International Society for the Systems Sciences. Available online at: http://isss.org/world/index.php

Jokinen E., 1992. The freshwater snails (Mollusca: Gastropoda) of New York State. The University of the State of New York, The State Education Department, The New York State Museum, Albany, NY: 112 p.

Jokinen E.H., 1982. Cipangopaludina chinensis (Gastropoda: Viviparidae) in North America, review and update. Nautilus, 96, 89-95.

Kim H. and Kim J.G., 2006. Heavy metal concentrations in the mollusc gastropod, Cipangopaludina chinensis malleata from Upo wetland reflect the level of heavy metals in the sediments. J. Ecol. Field Biol., 29, 453-460.

Lau S., Mohamed M., Tan Chi Yen A. and Su'Ut S., 1998. Accumulation of heavy metals in freshwater molluscs. Sci. Total Environ., 214, 113-121. 
Leighton B.J., Zervos S. and Webster J.M., 2000. Ecological factors in schistosome transmission, and an environmentally benign method for controlling snails in a recreational lake with a record of schistosome dermatitis. Parasitol. Int., 49, 9-17.

Morteau B., Triffault-Bouchet G., Galvez R., Martel L. and Leroueil S., 2009. Treatment of salted road runoffs using Typha latifolia, Spergularia canadensis, and Atriplex patula: a comparison of their salt removal potential. J. ASTM Int., 6, 7.

Olufemi M., Olayiwola T.O., Onomibre E.G., Momodu L.A. and Adegboyegun-King L.O., 2008. Trado-medicinal and nutritional values and biosafety of Lanistes libycus in Ijebu North, Southwest Nigeria. World Appl. Sci. J., 3, 921-925.

Orvain F., Le Hir P. and Sauriau P.G., 2003. A model of fluff layer erosion and subsequent bed erosion in the presence of the bioturbator, Hydrobia ulvae. J. Mar. Res., 61, 823-851.

Perron F. and Probert T., 1973. Viviparus malleatus, new record in New Hampshire. Nautilus, 87, 90.

Pienitz R., Roberge K. and Vincent W.F., 2006. Three hundred years of human-induced chance in an urban lake: paleolimnological analysis of Lac Saint-Augustin, Québec City, Canada. Can. J. Bot., 84, 303-320.

Ravera O., Beone G.M., Cenci R. and Lodigiani P., 2003. Metal concentrations in Unio pictorum mancus (Mollusca, Lamellibranchia) from of 12 Northern Italian lakes in relation to their trophic level. J. Limnol., 62, 121-138.

Risgaard-Petersen N., 2003. Coupled nitrification-denitrification in autotrophic and heterotrophic estuarine sediments: on the influence of benthic microalgae. Limnol. Oceanogr., 48, 93-105.

Rixon C.A.M., Duggan I.C., Bergeron N.M.N., Ricciardi A. and MacIsaac H.J., 2005. Invasion risks posed by the aquarium trade and live fish markets on the Laurentian Great Lakes. Biodivers. Conserv., 14, 1365-1381.
Roberge K., Pienitz R. and Arsenault S., 2002. Eutrophisation rapide du lac Saint-Augustin, Québec : étude paléolimnologique pour une reconsitution de la qualité de l'eau. Nat. Can., 26, 68-82.

Saha M., Sarkar S.K. and Bhattacharya B., 2006. Interspecific variation in heavy metal body concentrations in biota of Sunderban mangrove wetland, north east India. Environ. Int., 32, 203-207.

Shoultz-Wilson W.A., Urine J.M., Rickard J. and Black M.C., 2010. Comparison of metals concentrations in Corbicula fluminea and Elliptio hopetonensis in the Altamaha River system, Georgia, USA. Environ. Toxicol. Chem., 29, 2026-2033.

Stanczykowska A., Magnin E. and Dumouchel A., 1971. Study of 3 Viviparus malleatus (Gastropoda: Prosobranchia) populations of the Montreal region. Part 1: Growth, fecundity, biomass and annual production. Can. J. Zool., 49, 1431-1441.

Tartari G.A. and Mosello R., 1997. Metodologie analitiche e controlli di qualità nel laboratorio chimico dell'Istituto Italiano di Idrobiologiadel Consiglio Nazionale delle Ricerche. Documenta Ist. Ital. Idrobiol., 60, 160.

Thomann R.V., Connolly J.P. and Parkerton T.F., 1992. An equilibrium model of organic chemical accumulation in aquatic food webs with sediment interaction. Environ. Toxicol. Chem., 11, 615-629.

USDA - United States Department of Agriculture. Available online at: http://www.usda.gov/wps/portal/usda/usdahome

USEPA. 1992c Method 3020A. Acid Digestion of Aqueous Samples and Extracts for Total Metals for Analysis by GFAA Spectroscopy In Test Methods for Evaluating Solid Waste: Physical/Chemical Methods, SW-846 (3rd edn), United States Environmental Protection Agency, Washington, DC. Available online at: http://www.epa.gov/ waste/hazard/testmethods/sw846/pdfs/3020a.pdf 